by hetero-atoms. The various types of electronic transitions responsiblo for visible and ultra-violet spectra were classified, and the formulation of the species responsible for the spectroscopic properties of methiodides of pyridine, quinoline and related compounds was discussed. Prof. D. H. Hey, chairman of the final session, closed the meeting with a vote of thanks to the organizers of the symposium.

The widespread discussion of heterocyclic molecules in courses for Higher National Certificates in chemistry no doubt plays a part in creating an area of interest which makes it appropriate to hold a symposium of high academic standard on this subject in a college of technology. It was clear to all those attending the symposium that great credit is due to Dr. R. F. Robbins, head of the Department of Science at Hatfield College of Technology, for his imaginative forethought and efficient organization of such a successful gathering. All the participants will want also to thank the officers and administration of Hatfield College of Technology for making such satisfactory arrangements. Some of those present will have returned from this symposium wondering whether they might not expect the registration fees they pay for other conferences to be put as obviously as on this occasion towards the benefit of those who take part in the proceedings. Others concerned elsewhere in the finance of scientific education will have been impressed by what can be achieved when good scientists are given the means wherewith to fulfil their vision. There are probably some participants, and others who were unable to attend, who may regret that there is no permanent record of the scientific contributions presented at the symposium. P. B. D. DE LA MARE

1 Chemical Society Special Publication No. 3.

${ }_{2}^{2}$ Current Trends in Heterocyclic Chemistry, Albert and Shoppee (eds.) (Butterworths, 1958).

${ }^{3}$ Eisch, J. Org. Chem., 27, 1318 (1962).

\title{
COMPARATIVE NEUROCHEMISTRY
}

$F^{\mathrm{In}}$ IFTY-FOUR scientists from many different countries met at St. Wolfgang, Austria, during June 11-15 for the fifth International Neurochemical Symposium. The topic chosen for this meeting was "Comparative Neurochemistry" and the programme was designed to integrate the available data on differences in structure, chemical composition, metabolism, enzymatic activity and drug and hormone action in the nervous systems of invertebrate and vertebrate species. The meeting was interdisciplinary in approach, providing an opportunity for research workers in different fields to relate biochemical and pharmacological data to the morphology and function of nervous structures. The formal presentations were followed by lively and prolonged discussion in an atmosphere of informality which promoted the free exchange of information and ideas.

The Symposium opened with a discussion of the structural bases for similarities and differences in neural function in different species. The organization of nervous structures in invertebrates was described by Dr. G. A. Horridge (St. Andrews). The nervenet of the jellyfish, an anastomosing syncitium of motor neurones acting as a single cell, appears to provide a simple mechanism for the production of co-ordinated, rhythmic motions of the whole body. In the polychrtes, segmental and whole-body movements may be differentiated by a network of neurones and interneurones with symmetrical synaptic connexions providing a system for conduction of the nerve impulse in either direction. As pointed out by Prof. V. Hamberger (St. Louis), spontaneous swimming movements of the whole body prior to individuation of the limbs is the earliest manifestation of neuromuscular activity during the development of vertebrate embryos, although this may be preceded by precocious reflex activity in the case of the mammals. Sir Frances Knowles (Birmingham) summarized the present state of knowledge with respect to neurohumoral mechanisms of lower forms. In the phylogenetic sequence from molluses to arthropods, a reduction of neurosecretory elements with a concomitant increase in the complexity of neural structures and connexions appears to occur.

Qualitative and quantitative comparisons of the chemical composition of vertebrate and invertebrate nervous systems were presented by several of the participants. The bulk and complexity of the data do not permit ready summarization, but, in general, the basic similarities in composition of nervous tissues were more striking than the intraspecies differences, probably reflecting the fundamental unity of cellular organelles, and of membrane and myelin structures in nerve cells throughout the animal kingdom. For a given region of the nervous system the chemical composition, especially with respect to lipids of the myelin sheath, nucleic acid content, and patterns of free amino-acids, is characteristic of the stage of differentiation, and is relatively insensitive to changes in the external environment. Some interesting features unique to certain forms are the absence of detectable quantities of glycolipids in certain invertebrate species, and the occurrence of distinctive compounds such as threonine-ethanolamine phosphodiester in the brain of some fishes. Of intorest is the presence of amino-ethylphosphonic acid in the nervous system of some echinoderms.

Several papers were presented concerning comparative aspects of the transport of metabolites across nerve cell membranes. In a comprehensive review of blood-brain barrier systems, Dr. R. V. Coxon (Oxford) concluded that in the cœlenterates and lower phyla no effective barrier exists between nervous tissue and the extracellular fluid. The first indication of isolation of the nervous system from its surroundings occurs at the phylogenetie level of Branchiostoma, where a barrier to penetration of foreign substances appears at a relatively late stage of development in higher forms, and appears to be associated with increased vascularization and proliferation of glial elements. The maintenance of ionic gradients in nervous tissues of various specios in passing from marine to freshwater and terrestrial environments was discussed by Dr. H. Hillman (London). Although the degree of regulation of extracellular cations may vary widely, in all species studied, the nerve cell behaves fundamentally as a potassium electrode, and the intracellular/extracellular $\mathrm{K}^{+}$ratio is regulated in conformity to the Nernst equation.

The metabolism of the brain in relation to hibernation received special attention. Prof. A. V. Palladin (Kiev) described a marked reduction in the in vivo 
incorporation of labelled amino-acids into brain proteins during hibernation. The biochemical basis of the dramatic increase in body temperature and metabolic rate during arousal from hibernation was discussed by Dr. L. Mokrasch (Waverloy). Changes in the activities of oxidative and glycolytic enzymes do not appear to play significant part, but it appears possible that activation of phosphorylase, and enzymes (adenosine triphosphatese and acyl phosphatase) capable of cleaving high-energy compounds may be implicated in the mochanism of heat production during arousal.

The distribution of neurohypophyseal peptides in different classes was traced by Prof. H. Heller (Bristol). In the cyclostomes, fish, amphibia and birds, the principal antidiuretic peptide is 8-arginineoxytocin (vasotocin); in most mammals, including the ruminants, arginine-vasopressin is typical; whilo in the pig and hippopotamus lysine-vasopressin is characteristic. A basic phylogenetic division in distribution of the octapoptides may be traced, but important exceptions to the general pattern exist.

Dr. D. B. Carlisle (London) posed a provocative quostion for the participants in the title of his paper "What makes tho Shrimp's Heart Beat Faster?" One answer proved to be "another shrimp !": but in all, six substances (including two polypeptides, and four indole derivatives) isolated from extracts of the shrimp pericardial organ will produce the same effect. The most potent compound has been identified as 5:6-dihydroxytryptamine. This compound probably serves to produce instantaneous effocts on the heart beat, while the polypeptides appear to account for long-term responses during prolonged stress. Other papers were concerned with the distribution and functions of acetylcholine, indoles, cate- cholamines and other possible neurotransmitter substances in differont species.

In the final session, devoted to comparative neuropharmacology, the basis of specios differences in the sensitivity to drugs was considered. The selective toxicity of piporazine, an anthelmintic agent, was shown by Dr. E. Bucding (Baltimore) to be related to its ability to produce a selective neuromuscular blocking action in Ascaris without affocting the neuromuscular junction of the mammalian host. As pointed out by Dr. D. Richter (Carshalton) in the final discussion, the practical value of comparative neurochemistry is evident in tho exploitation of such intraspecios differences for the development of new anthelmintics and pesticides.

Many excellent papers and interesting commentaries have been nocessarily omittod from this brief report. I would be remiss, however, if I failed to commont on the fine tissue culture experiments on in vitro myelin formation by Prof. Margaret Murray (New York), the elegant electronmicrographs of norve membranes by Dr. J. D. Robertson (Waverley), the stimulating speculations concerning the macro-molecular basis of coding in the memory mechanism by Prof. F. $O$. Schmitt (Boston), and the techniques used by Dr. $\mathrm{H}$. Blaschko (Oxford) in estimating the amine oxidase activity of the Malpighian tubules in the cockroach. The proceedings of the Symposium are being published in the form of a book, Comparative Neurochemistry, edited by Dr. D. Richter.

During our stay, the participants were entertained at receptions and banquets by the Mayor of St. Wolfgang, the Mayor of Salzburg and the Governmont of Uppor Austria. The hospitality of our Austrian hosts and the beauty and gaiety of the Salzkammergut made this Symposium an exccedingly enjoyable as well as scientifically profitable occasion. W. C. MCMurRaY

\section{THE COLONIAL DEVELOPMENT CORPORATION}

\begin{abstract}
THE annual report and statement of accounts of the Colonial Development Corporation for the year ended December 31, 1961*, follows the pattern of the previous report. However, the form of the accounts has been altered to givo offect to the changes in financial arrangements which the Government announced in April 1961; deferred Government interest currently accruing in 1961 is charged for the first time in the accounts to the extent of some $£ 800,000$. The 102 approved projects at the end of the year, totalling $£ 115,770,000$, included thirteen new projects totalling some $£ 10$ million, of which the largest were the Swaziland Railway Board (£4.25 million), the Trinidad Mortgage Agency Co., Ltd. (£1-97 million), the Land Development and Settlement Board, Kenya ( $\$ 1.5$ million) and Northern Rhodesia Africa Housing ( $£ 1$ million). Four projects were abandoned and one existing project was split into two projects. Of the total commitmonts, $£ 16.454$ million was in the Caribbean region, $£ 20.315$ million in the Far East, $£ 22.484$ million in East Africa, $£ 22-743$ million in Central Africa, $£ 20 \cdot 347$ million in the High Commission territories, and $£ 13.427$ million in West Africa. Functionally, 54.8 per cent of the committed capital in 1961 was for basic development,
\end{abstract}

-Colonial Development Corporation. Annual Report and Statement of Accounts for year ended 31st December, 1961. Pp. vi + 90. (London: H.M. Stationery Office, 1961). 5s. 6d. net.
34.4 per cent for primary production and processing, and $\mathbf{1 0 . 8}$ per cent for commerce and industry.

While the British Exchequer remains the chief source of the Corporation's finance, a steadily increasing part of its investment is financed either by self-generated funds or by loans from sources other than the Exchequer. It is emphasized, however, that the Corporation's operations are more immediately likely to be restricted by territories becoming independent with consequent exclusion of the Corporation, despite their continued need for its help, than by shortage of funds, and the total of new projects under serious consideration fell from 38 to 26 during the year. The present terms of reference in independent territories are, however, now under review.

The report indicates the type of schome which will receive serious consideration by the Corporation once compliance is established with the Corporation's normal powers. Priority is increasingly given to schemes which help the inhabitants of the country to establish themselves as members of an economically self-supporting and ordered community, for example, agricultural small-holder projects, housoholder mortgage finance companies and local industrial development agencies. Through the small-holder schemes also, production of tea in Konya, palm oil in Malaya, tobacco at Kasungu, Nyasaland, and sugar in Swazi- 